\title{
KEMAMPUAN PEMAHAMAN KONSEP MATEMATIKA SISWA SMA PADA MODEL DISCOVERY LEARNING DAN MODEL AUDITORY INTELLECTUALLY REPETITION
}

\author{
Fefti Puji Lestari ${ }^{1}$, Ristontowi ${ }^{2}$ \\ Program Studi Pendidikan Matematika Universitas Muhammadiyah Bengkulu 1,2 \\ tontowi1966@gmail.com²
}

\begin{abstract}
ABSTRAK
Penelitian ini bertujuan untuk mengetahui apakah ada perbedaan kemampuan pemahaman konsep matematika siswa yang diajarkan dengan model Discovery Learning, model Auditory Intellectually Repetition (AIR), serta model konvensional. Penelitian ini dilakukan pada tahun ajaran 2020/2021. Penelitian ini merupakan jenis penelitian eksperimen semu (quasi experiment). Pada penelitian ini populasinya yaitu siswa kelas XII IPA SMAN 3 Bengkulu Selatan. Sedangkan sampelnya yaitu seluruh kelas populasi yang dipilih secara random yaitu kelas XII IPA 1 dengan model discovery learning sebagai kelas eksperimen I, kelas XII IPA 2 dengan model Auditory Intellectually Repetition (AIR) sebagai kelas eksperimen II, dan kelas XII IPA 3 dengan menggunakan model konvensional sebagai kelas kontrol. Dari hasil penelitian diperoleh adanya perbedaan kemampuan pemahaman konsep antara model Discovery Learning, model Auditory Intellectually Repetition (AIR) serta model konvensional. Dari skor post-test siswa menunjukkan bahwa model discovery learning memberikan hasil yang lebih baik daripada model auditory intellectually repetition (AIR) dan model konvensional.
\end{abstract}

Kata kunci : discovery learning, auditory intellectually repetition

\begin{abstract}
The purpose of this study is to see if there are any differences in students' ability to understand mathematical concepts taught using the Discovery Learning model, the Auditory Intellectually Repetition (AIR) model, and the traditional model. This study was carried out during the academic year 2020/2021. This research is of the quasi-experimental variety. The population for this study was class XII IPA SMAN 3 Bengkulu Selatan. While the samples were all population classes chosen at random, the experimental classes were class XII IPA 1 with discovery learning model as experimental class I, class XII IPA 2 with Auditory Intellectually Repetition (AIR) model as experimental class II, and class XII IPA 3 with conventional models as experimental class III. According to the study's findings, there were differences in concept understanding between the Discovery Learning model, the Auditory Intellectually Repetition (AIR) model, and the conventional model. The posttest results of the students revealed that the discovery learning model outperformed the auditory intellectually repetition (AIR) model and the conventional model.
\end{abstract}

Keywords : discovery learning, auditory intellectually repetition 


\section{PENDAHULUAN}

Pendidikan adalah aspek dasar untuk menentukan arah kesuksesan bangsa. Hamzah dan Muhlishrarini (2014) mengatakan bahwa kemajuan suatu bangsa dikendalikan oleh peningkatan pendidikan bagi generasi muda bangsa. UU Sistem Pendidikan Nasional No. 20 Tahun 2003 menyatakan bahwasanya pendidikan merupakan suatu usaha yang sadar dan terstruktur untuk menjadikan suasana belajar dan kegiatan belajar- mengajar agar siswa secara efektif mengembangkan kemampuannya untuk memiliki kekuatan, ketenangan, watak, pengetahuan, akhlak mulia, dan kemampuan yang diperlukan dirinya, orang lain, masyarakat, bangsa dan negara (Sagala, 2013).

Salah satu mata pelajaran yang harus dipelajari dalam dunia pendidikan adalah matematika. Pembelajaran matematika diajarkan kepada siswa saat masih di sekolah dasar hingga ke tingkat perguruan tinggi (Mustikasari et al., 2017). Matematika merupakan ilmu yang mempelajari mengenai logika terhadap bentuk, susunan besaran, dan ide-ide terkait yang berbeda dengan jumlah yang banyak dan digolongkan menjadi tiga bidang yaitu bidang aljabar, analisis, dan geometri (Hamzah dan Muhlishrarini, 2014). Matematika juga adalah aset yang penting dalam menumbuhkan batas penalaran siswa dan pemahaman konsep siswa pada proses belajar-mengajar. Menurut Subchan et al. (2018) bahasa matematika (dimanfaatkan dalam matematika) sangatlah efektif dan merupakan aset yang berguna dalam menyatakan konsep-konsep matematika, menyusun kembali konsep atau menata suatu penyelesaian dengan cara matematis sesudah dilakukannya penyelidikan, dan terutama untuk komunikasi.

Dalam pembelajaran matematika pemahaman konsep merupakan komponen mendasar yang wajib dikuasai siswa. Oleh sebab itu, siswa dituntut untuk meningkatkan pemahaman konsep. Pemahaman konsep matematika merupakan kompetensi untuk menyerap, memahami ide-ide matematika, memahami konsep serta membedakan sejumlah konsep-konsep yang saling terpisah secara bermakna dalam kondisi masalah yang lebih luas (Wijaya et al., 2018). Hal ini sejalan dengan Sarniah et al. (2019 : 88) yang menyatakan bahwa memahami konsep matematika, yaitu kemampuan dalam menegaskan hubungan antar konsep dan memanfaatkan konsep serta algoritma, secara luwes, cermat, efektif, dan tepat dalam pemecahan masalah merupakan salah satu tujuan pembelajaran matematika yang sudah ditentukan dalam kurikulum 2013. Dengan semakin tingginya pemahaman siswa terhadap ide/konsep matematika maka akan berpengaruh juga pada prestasi siswa.

Namun, dalam meningkatkan pemahaman konsep matematika tidaklah mudah karena kesalahan dalam penyampaian pengetahuan atau konsep pada jenjang sebelumnya sangat berpengaruh pada tingkat pendidikan selanjutnya. Sebab dalam matematika konsep saling terkait satu dengan yang lainnya. Tanpa adanya pemahaman konsep siswa akan kesulitan untuk dapat menerima materi baru di tingkat lanjutan dan siswa juga akan kesulitan dalam mengaplikasikan materi matematika dalam kehidupan nyata. Menurut Febriyanto et al. (2018) pemahaman konsep sangat berarti sebab jika siswa memahami suatu ide/konsep, maka siswa dapat mengingat pelajaran matematika yang sudah mereka pelajari dalam kurung waktu yang lama. Mustamin dan Kusumayanti (2019) menyatakan untuk mengatasi masalah tersebut sangat dibutuhkan tindakan yang tepat agar bisa meningkatkan kemampuan pemahaman konsep siswa. 
Berdasarkan observasi dan pengalaman pada pelaksanaan PLP II di SMA Negeri 3 Bengkulu Selatan bahwa kemampuan pemahaman konsep yang siswa miliki belum menunjukkan kemampuan pemahaman konsep yang baik. Hal ini dapat dilihat dari kurangnya kemampuan pemahaman konsep matematika berdasarkan indikator pemahaman konsep. Pada proses pembelajaran, ketika guru menyuruh siswa untuk menjelaskan kembali materi yang sudah dipelajari, hanya beberapa siswa yang mampu menjelaskan ulang materi tersebut. Selain itu, siswa juga kesulitan dalam memahami serta menyelesaikan soal yang sedikit berbeda dari contoh yang guru berikan. Bahkan masih banyak siswa yang bertanya apa yang dicari dari soal yang diberikan. Hal ini disebabkan oleh siswa belum paham akan konsep dari materi yang diajarkan dan hanya berfokus dengan contoh soal yang telah guru berikan sehingga siswa masih kesulitan untuk menjelaskan ulang konsep yang dipelajari menggunakan bahasanya sendiri.

Dalam matematika konsep antar materi saling terkait satu dengan yang lain. Pada saat kegiatan pembelajaran dan siswa diberikan soal yaitu materi statistika siswa masih belum paham akan konsep statistika dan masih mendapati jawaban siswa yang salah, dimana materi statistika erat hubungannya dengan materi peluang. Menurut Hadi et al. (2018) seseorang tidaklah mungkin untuk memahami statistika secara sempurna tanpa memahami apa arti peluang itu sendiri. Dengan demikian jika siswa telah mempelajari peluang, siswa akan lebih mudah dalam mengerti serta memahami materi statistika yang akan diajarkan.

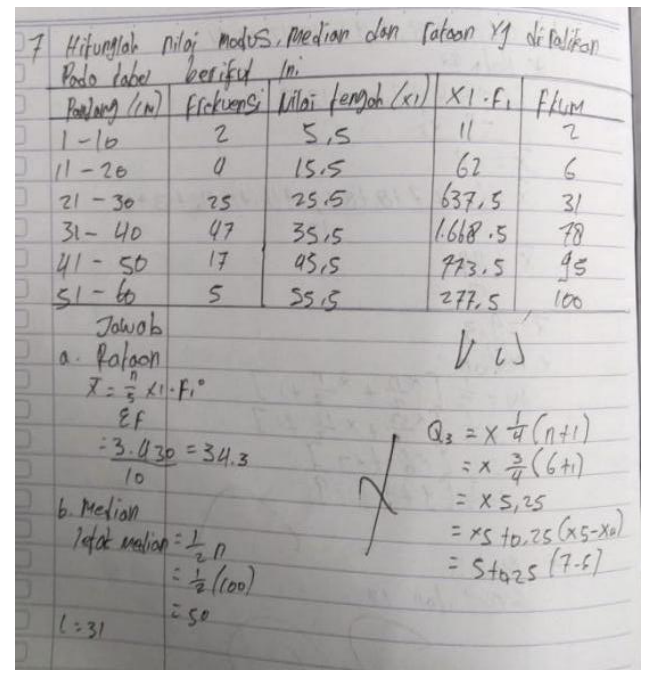

Gambar 1. Hasil jawaban siswa

Dapat dilihat pada gambar 1 bahwa siswa melakukan kesalahan dalam mengerjakan soal yang telah guru berikan dimana siswa kesulitan untuk mengklasifikasikan konsep berdasarkan konsep tertentu, menggunakan, memanfaatkan, serta mengoperasikan penyelesaian soal tersebut. Selain itu pada jawaban siswa terlihat bahwa siswa belum mengerti akan konsep materi yang dipelajari serta siswa juga kesulitan mengetahui apa yang dicari dari soal yang membuat siswa kesulitan untuk dapat menyelesaikan permasalahan yang ada.

Pada kegiatan pembelajaran yang berlangsung di sekolah terlihat guru masih menerapkan pembelajaran tradisional atau pembelajaran konvensional, dimana peran guru lebih dominan daripada siswa. Guru berperan aktif dalam menyampaikan dan 
memberikan penjelasan materi yang berkaitan dengan pembelajaran. Sehingga siswa yang ada hanya mendengarkan penyampaian materi yang dijelaskan oleh guru. Hal seperti ini membuat siswa menjadi pasif dalam memahami konsep-konsep yang dipelajari. Damayana et al. (2019) mengatakan jika pembelajaran yang berpusat pada guru terus dilakukan akan menyebabkan siswa menjadi pasif dan kurang kreatif untuk menyampaikan ide pikiran dan siswa akan kesulitan untuk dapat menyelesaikan soal-soal yang guru berikan. Dengan demikian menerapkan model pembelajaran konvensional tidaklah efektif untuk menumbuhkan kemampuan pemahaman konsep siswa.

Berdasarkan dari hasil pengamatan ketika PLP II tersebut dapat disimpulkan kalau kemampuan pemahaman konsep siswa di SMAN 3 Bengkulu Selatan masih rendah. Salah satu faktor penyebab rendahnya pemahaman konsep siswa karena pendekatan pembelajaran yang dilakukan kurang menarik atau monoton dimana cenderung didominasi oleh guru serta kurangnya guru dalam memberikan kesempatan kepada siswa untuk dapat melakukan penemuan ataupun pembelajaran secara mandiri. Faktor lainnya yaitu kurang optimalnya guru dalam memanfaatkan model pembelajaran yang ada. Menurut Ompusungu (Wijaya et al., 2018) faktor penyebab rendahnya kemampuan pemahaman konsep siswa yaitu prosedur pembelajaran yang dilakukan oleh guru masih menerapkan metode konvensional, dimana guru memperlakukan siswa sebagai objek belajar dan guru lebih berperan dalam pembelajaran. Adapun upaya yang bisa dilakukan untuk meningkatkan pemahaman konsep siswa adalah dengan menerapkan model pembelajaran yang tepat.

Ada banyak model pembelajaran yang bisa diterapkan oleh guru dalam pembelajaran matematika di antaranya yaitu model Discovery Learning dan model Auditory Intellectualy Repetition (AIR). Kedua model pembelajaran ini tentunya memiliki karakteristik yang berbeda dalam penerapannya dan bagaimana pengaruhnya terhadap kemampuan pemahaman konsep siswa. Dengan menerapkan model pembelajaran discovery learning, model auditory intellectually repetition (AIR), dan model konvensional dapat membantu guru untuk mengetahui apakah ada perbedaan antara pemahaman konsep matematika siswa sebelum dan sesudah diterapkannya model pembelajaran. Selain itu, guru juga dapat mengetahui model pembelajaran mana yang lebih efektif dalam menumbuhkan pemahaman konsep matematika siswa.

\section{METODE}

Penelitian ini menggunakan jenis penelitian eksperimen semu (quasi experiment). Kelas dibagi menjadi dua kelompok yaitu kelas eksperimen dan kelas kontrol. Kelas eksperimen terbagi menjadi dua yaitu kelas eksperimen I dengan model Discovery Learning, kelas eksperimen II dengan model Auditory Intellectually Repetition (AIR) serta model konvensional diterapkan pada kelas kontrol.

Penelitian ini dilakukan di SMAN 3 Bengkulu Selatan tahun ajaran 2020/2021. Populasi dalam penelitian ini yaitu kelas XII IPA SMAN 3 Bengkulu Selatan. Sedangkan sampelnya yaitu seluruh kelas populasi yang terdiri dari kelas XII IPA 1, kelas XII IPA 2, dan kelas XII IPA 3 yang berjumlah 74 orang siswa. Penelitian ini menggunakan sampel acak sederhana (simple random sampling) yang dipilih dengan cara acak. 
Variabel dalam penelitian ini terdiri dari variabel bebas dan variabel terikat. Variabel bebas yaitu model discovery learning dan auditory intellectually repetition (AIR) sedangkan variabel terikatnya yaitu kemampuan pemahaman konsep matematika siswa.

Pada penelitian ini, sebelum siswa diberi perlakuan terlebih dahulu siswa diberikan tes awal (pre-test) yang sama. Tes awal ini dilakukan untuk mengetahui kemampuan awal siswa sebelum diberi perlakuan. Kemudian siswa mengikuti proses pembelajaran dimana model discovery learning diajarkan pada kelas eksperimen I, model auditory intellectually repetition diajarkan pada kelas eksperimen II sedangkan model konvensional diterapkan pada kelas kontrol. Selanjutnya siswa kembali diberi tes akhir yang sama untuk mengetahui apakah terdapat perbedaan antara kemampuan pemahaman konsep siswa sebelum dan sesudah diberi perlakuan.

Teknik pengumpulan data dalam penelitian ini yaitu dengan menggunakan tes yang terdiri dari soal uraian. Sedangkan untuk teknik analisis data yang digunakan yaitu uji normalitas data dan uji homogenitas varians. Uji normalitas data menggunakan rumus kolmogorov-smirnov sedangkan uji homogenitas varians menggunakan uji barleth. Setelah memenuhi uji normalitas dan homogenitas maka dilakukan uji ANOVA. Uji ANOVA yang digunakan yaitu ANOVA satu jalur (one way anova).

\section{HASIL DAN PEMBAHASAN}

Pelaksanaan penelitian ini dilakukan di SMAN 3 Bengkulu Selatan dengan memakai tiga kategori sampel. Sebelum melaksanakan proses pembelajaran, dilakukan tes awal (pre-test), dilanjutkan dengan proses belajar-mengajar dengan memberikan perlakuan pada setiap kelas secara berbeda. Kemudian diberikan posttest yang sama pada semua kelas sampel. Kemudian data pre-test dan post-test dianalisis untuk mengetahui ada tidaknya perbedaan kemampuan setiap kelompok siswa dalam memahami konsep matematika. Dari data post-test yang dianalisis, dapat terlihat model mana yang memberikan hasil yang lebih baik. Hal ini dapat dilihat pada tabel 1 berikut ini :

Tabel 1. Data hasil pre-test dan post-test kemampuan pemahaman konsep matematika siswa

\begin{tabular}{lcccccc}
\hline \multicolumn{1}{c}{ Data } & \multicolumn{2}{c}{$\begin{array}{c}\text { Discovery Learning } \\
\text { (Eksperimen I) }\end{array}$} & \multicolumn{2}{c}{$\begin{array}{c}\text { Auditory Intellectually } \\
\text { Repetition (AIR) } \\
\text { (Eksperimen II) }\end{array}$} & \multicolumn{2}{c}{$\begin{array}{c}\text { Konvensional } \\
\text { (Kontrol) }\end{array}$} \\
\hline & Pre-test & Post-test & Pre-test & Post-test & Pre-test & Post-test \\
\hline Jumlah & 244 & 516 & 247 & 497 & 224 & 399 \\
Rata-rata & 10,167 & 21,5 & 9,9 & 19,88 & 8,96 & 15,96 \\
Skor tertinggi & 17 & 34 & 16 & 30 & 18 & 27 \\
Skor terendah & 6 & 10 & 6 & 11 & 6 & 10 \\
Varians & 12.145 & 39,304 & 10,193 & 24,110 & 6,373 & 14,707 \\
Simpangan baku & 3,485 & 6,269 & 3,193 & 4,910 & 2,524 & 3,835 \\
\hline
\end{tabular}

Berdasarkan tabel 1 di atas menunjukkan kalau nilai post-test kemampuan pemahaman konsep matematika siswa pada kelas eksperimen memiliki rata-rata paling tinggi sebaliknya kelas kontrol mendapatkan rata-rata yang lebih rendah. Hal ini menjelaskan bahwa kemampuan pemahaman konsep siswa menjadi berbeda sesudah diberi perlakuan. 
Terlihat pada kelas eksperimen I yang menggunakan model Discovery Learning mempunyai nilai rata-rata awal 10,167 menjadi 21,5 pada nilai rata-rata akhir. Sedangkan kelas eksperimen II dengan model Auditory Intellectually Repetition (AIR) mempunyai rata-rata awal 9,9 setelah diberi perlakukan rataratanya menjadi 19,88. Sedangkan nilai rata-rata awal pada kelas kontrol dengan model konvensional yaitu 8,96 dan mejadi 15,96 pada nilai rata-rata akhir.

Berdasarkan hasil rata-rata post-test siswa setelah diberi perlakuan menunjukkan kalau penerapan model Discovery Learning (eksperimen I) dan model Auditory Intellectually Repetition (eksperimen II) dapat meningkatkan kemampuan pemahaman konsep matematika siswa.

Dari hasil uji ANOVA dapat disimpulkan bahwa ada perbedaan antara kemampuan pemahaman konsep matematika siswa pada kelas eksperimen I, kelas eksperimen II, serta kelas kontrol. Hal ini ditunjukkan oleh jumlah skor total yang diperoleh oleh ketiga kelas yang mempunyai rentang yang berbeda. Dimana pada uji ANOVA menjelaskan bahwa nilai $\mathrm{F}_{\text {hitung }}>\mathrm{F}_{\text {tabel, }}$, maka $\mathrm{H}_{0}$ ditolak.

Dalam menumbuhkembangkan kemampuan pemahaman konsep model discovery learning, model auditory intellectually repetition (AIR), dan model konvensional mempunyai karakteristik yang berbeda. Pada model discovery learning siswa belajar proaktif dan mampu mandiri dalam menemukan dan memecahkan masalah. Pada model auditory intellectually repetition siswa diharuskan untuk dapat melibatkan seluruh alat indra yang dimiliki yang mementingkan tiga aspek yaitu auditory, intellectually, dan repetition (pengulangan). Dan pada model konvensional siswa hanya mendengarkan serta menerima informasi yang disampaikan oleh guru, dimana guru berperan dominan pada proses pembelajaran.

Berdasarkan hal tersebut, terdapat dua pasang perlakuan yang memberikan hasil kemampuan pemahaman konsep matematika siswa yang berbeda. Untuk mengetahui pasangan mana yang memberikan hasil kemampuan pemahaman konsep yang berbeda adalah dengan menggunakan uji Beda Nyata Terkecil (BNT). Uji BNT adalah uji lanjutan dari uji ANOVA (analisis varians). Ringkasan uji BNT dapat dilihat pada tabel 2 .

Tabel 2. Ringkasan BNT

\begin{tabular}{ccccc}
\hline $\begin{array}{c}\text { Selisih rata-rata } \\
\text { antar perlakuan }\end{array}$ & $\left|\overline{x_{i}}-\overline{x_{j}}\right|$ & BNT $(\alpha=0,05)$ & Kategori & Kesimpulan \\
\hline$\left|\overline{x_{1}}-\overline{x_{2}}\right|$ & 1,62 & 2,867372 & $\left|\overline{x_{1}}-\overline{x_{2}}\right|<B N T$ & Terima $\mathrm{H}_{0}$ \\
$\left|\overline{x_{1}}-\overline{x_{3}}\right|$ & 5,54 & 2,867372 & $\left|\overline{x_{1}}-\overline{x_{3}}\right|>B N T$ & Tolak $\mathrm{H}_{0}$ \\
$\left|\overline{x_{2}}-\overline{x_{3}}\right|$ & 3,92 & 2,867372 & $\left|\overline{x_{2}}-\overline{x_{3}}\right|>B N T$ & Tolak $\mathrm{H}_{0}$ \\
\hline
\end{tabular}

Dari tabel 2 menunjukkan bahwa tidak terdapat perbedaan antara kemampuan pemahaman konsep matematika siswa yang diberi model pembelajaran Discovery Learning (eksperimen I) dan model Auditory Intellectually Repetition (AIR) (eksperimen II). Dari hasil uji BNT yang diperoleh pasangan itu dapat dilihat bahwa nilai 1,62 $<2,867372$, maka $\mathrm{H}_{0}$ diterima, berarti tidak terdapat perbedaan kemampuan pemahaman konsep matematika siswa. 
Dari tabel juga terlihat bahwa terdapat perbedaan antara kemampuan pemahaman konsep matematika siswa yang diajarkan dengan model pembelajaran Discovery Learning dan model konvensional. Dimana nilai $\left|\overline{x_{1}}-\overline{x_{3}}\right|>B N T$, maka tolak $\mathrm{H}_{0}$ berarti terdapat perbedaan. Hal ini sejalan dengan penelitian yang dilakukan oleh Surur dan Oktavia (2019) yang menyatakan kalau tingkat pemahaman konsep matematika siswa yang diajarkan dengan pembelajaran Discovery Learning dan model pengajaran langsung terdapat perbedaan yang signifikan. Khamidah dan Warniasih (2019) menyatakan jika dilihat dari pemahaman konsep matematis siswa model Discovery Learning lebih efektif daripada menggunakan model pembelajaran konvensional.

Untuk model pembelajaran Auditory Intellectually Repetition dan model pembelajaran konvensional juga terdapat perbedaan. Hal ini dapat dilihat dari tabel dimana $\left|\overline{x_{2}}-\overline{x_{3}}\right|>B N T$, maka tolak $\mathrm{H}_{0}$, berarti terdapat perbedaan kemampuan pemahaman konsep siswa. Hal ini sejalan dengan pendapat Sarniah et al. (2019) yang menyimpulkan kalau kemampuan pemahaman konsep matematis siswa yang memakai model Auditory Intelletually Repetition (AIR) memberikan hasil lebih baik dibandingkan dengan model pembelajaran biasa/konvensional.

Dari analisis data yang telah dilakukan maka terdapat perbedaan antara kemampuan pemahaman konsep siswa yang memakai model discovery learning, model auditory intellectually repetition (AIR), dan model konvensional yang diterapkan pada siswa SMAN 3 Bengkulu Selatan. Pada skor post-test siswa terlihat bahwa kelas eksperimen I dengan model discovery learning memiliki nilai paling tinggi daripada model auditory intellectually repetition (AIR) maupun model konvensional.

Dalam menerapkan model pembelajaran discovery learning terdapat beberapa fase yang dilakukan dalam upaya untuk menumbuhkan pemahaman konsep matematika siswa terhadap materi yang disampaikan. Menurut Sumardyono, et al. (2016) langkah-langkah model pembelajaran discovery learning yaitu dimulai dengan guru memberikan stimulus/rangsangan kepada siswa sehingga menimbulkan kebingungan yang akan membuat siswa berkeinginan untuk mengetahui/menyelidiki sendiri materi secara lebih lanjut, guru memberikan kesempatan kepada siswa untuk mengidentifikasi masalah yang berkaitan atau sesuai dengan pelajaran, dimana kemudian siswa menetapkan dugaan sementara (hipotesis), siswa diberi waktu untuk mengumpulkan berbagai informasi baik dari dari buku maupun mengamati objek secara langsung sehingga siswa akan menumbuhkan pengetahuannya dengan sendiri tanpa disadarinya, siswa melakukan pengolahan data yang telah didapatkan yang kemudian diverifikasi sehingga mengarahkan siswa kepada konsep yang hendak dicapai, semua data yang telah diolah kemudian diperiksa secara teliti oleh siswa untuk membuktikan benar tidaknya dugaan yang telah dirumuskan sebelumnya, terakhir siswa menarik kesimpulan dari seluruh rangkaian tahapan yang telah dilalui sehingga dapat menjawab hipotesis yang telah ditetapkan sebelumnya.

Pada proses pembelajaran yang menerapkan model discovery learning membuat siswa lebih tertarik untuk belajar, sebab dengan menggunakan model ini siswa belajar secara aktif dengan mencari (menemukan) sendiri informasi maupun pengetahuan sehingga setelah diperoleh informasi siswa secara bersama-sama mendiskusikannya sehingga dapat merumuskan hipotesis. Siswa mampu menemukan sendiri konsep materi yang hendak dicari melalui kemampuan mereka sendiri. Namun penemuan yang mereka dapatkan tidak lepas dari bimbingan serta bantuan 
dari guru yang merupakan fasilitator pada proses belajar-mengajar. Dengan adanya guru sebagai fasilitator membuat proses pembelajaran menjadi terarah dan dapat terlaksana dengan baik dan mencapai tujuan yang diharapkan.

Model discovery learning juga membuat siswa lebih aktif dan siswa dapat mengingat lebih lama informasi yang telah didapat. Dalam menerapkan model discovery learning terlihat bahwa model ini mampu menumbuhkan kemampuan pemahaman konsep siswa. Hal ini terlihat dari kemampuan pemahaman konsep matematika siswa yang lebih baik dibandingkan sebelum diterapkannya model discovery learning.

Selanjutnya, pada model pembelajaran AIR dimana pada pembelajaran ini siswa melakukan 3 tahapan. Tahap pertama yaitu Auditory, pada tahap ini siswa melibatkan indera pendengaran untuk mendukung berlangsungnya pembelajaran dimana siswa dibagi menjadi kelompok kecil yang berjumlah 5 orang di setiap kelompok. Kemudian guru membagikan LKS sebagai bahan ajar yang diberikan. Pada tahap ini guru meminta perwakilan kelompok untuk membacakan soal yang ada pada LKS. Sehingga siswa dapat mendengarkan dengan seksama. Dengan demikian dapat melatih indera pendengaran siswa dalam proses belajar-mengajar.

Pada tahap selanjutnya yaitu Intellectually, siswa diminta mengerjakan soal yang ada di LKS secara bersama-sama dengan anggota kelompok. Sehingga siswa dapat menemukan jawaban dari permasalahan yang ada di LKS. Dan pada tahapan Repetition (pengulangan), siswa diminta mengungkapkan kembali materi ataupun pembahasan yang telah dilakukan dimana perwakilan kelompok mempresentasikan hasil kerja kelompoknya di depan kelas secara bergantian.

Proses pembelajaran yang dilakukan dengan model auditory intellectually repetition terlihat bahwa siswa antusias dalam proses pembelajaran, siswa membaca dan mengamati masalah yang disajikan sehingga menimbulkan pemahaman sendiri. Siswa juga aktif berdiskusi dan aktif dalam bertanya baik kepada guru maupun teman kelompoknya. Selain itu guru juga memberikan tugas untuk dikerjakan sebagai bentuk untuk mengetahui apakah siswa tersebut sudah memahami materi yang disampaikan atau belum, dengan demikian diharapkan siswa dapat memperdalam pengetahuannya terhadap materi yang telah disampaikan.

Sedangkan untuk pembelajaran konvensional dilakukan dengan metode pembelajaran langsung/ceramah dimana pembelajaran diambil alih oleh guru sedangkan siswa hanya sebagai objek atau pendengar. Sehingga membuat minat siswa kurang terhadap proses pembelajaran. Hal ini menyebabkan siswa cenderung pasif dan jika dilihat dari nilai post-test kemampuan pemahaman konsep siswa tidak menunjukkan perubahan yang signifikan.

\section{SIMPULAN DAN SARAN}

Berdasarkan dari penjelasan hasil di atas maka diperoleh kesimpulan bahwa terdapat perbedaan antara kemampuan pemahaman konsep matematika siswa yang diajarkan dengan model discovery learning, model auditory intellectually repetition (AIR) dan model konvensional di SMAN 3 Bengkulu Selatan. Dari skor post-test siswa menunjukkan bahwa model discovery learning memberikan hasil yang lebih baik daripada model auditory intellectually repetition (AIR) dan model konvensional.

Dapat disarankan agar guru mata pelajaran matematika dapat menerapkan model pembelajaran discovery learning di sekolah sebagai upaya dalam menumbuhkan pemahaman siswa terhadap konsep materi yang diajarkan.. Sekolah 
hendaknya ikut mendukung dalam penerapan model pembelajaran discovery learning dengan menyediakan sarana dan prasarana agar mencapai hasil yang maksimal.

\section{DAFTAR PUSTAKA}

Damayana, R., Andinasari, dan Lusiana. 2019. Peningkatan Pemahaman Konsep Peluang Melalui Model Discovery Learning. Lentera Pendidikan, Jurnal Ilmu Tarbiyah dan Keguruan, Vol. 22(2) : 223-232.

Febriyanto, B., Haryanti, Y. D., dan Komalasari, O. 2018. Peningkatan Pemahaman Konsep Matematis Melalui Penggunaan Media Kantong Bergambar Pada Materi Perkalian Bilangan di Kelas II Sekolah Dasar. Jurnal Cakrawala Pendas, Vol. 4(2) : 32-44.

Hadi, S., Gunawan, I., dan Dalle, J. 2018. Statistika Inferensial Teori dan Aplikasinya. Depok: PT. Rajagrafindo Persada.

Hamzah, A. dan Muhlishrarini. 2014. Perencanaan dan Strategi Pembelajaran Matematika. Depok: PT. Rajagrafindo Persada.

Khamidah dan Warniasih, K. 2019. Efektivitas Model Discovery Learning Ditinjau dari Pemahaman Konsep Matematis Siswa Kelas XI IPS SMA Negeri 1 Gamping. Delta: Jurnal Ilmiah Pendidikan Matematika, Vol. 7(1) : 27-36.

Mustamin, S.H. dan Kusumayanti, A. 2019. Kemampuan Pemahaman Konsep Matematika Melalui Model Pembelajaran Auditory Intellectually Repetition (AIR) Pada Siswa. Alauddin Journal of Mathematics Education, Vol. 1(2) : 9097.

Mustikasari, M., Isnani, dan Susongko, P. 2017. Keefektifan Model Pembelajaran Talking Stick Berbantu Media Microsoft Power Point Terhadap Prestasi Belajar Matematika Ditinjau dari Kemampuan Numerik Materi Pokok Statistika. Jurnal Pendidikan MIPA Pancasakti, Vol. 1(1) : 65-71.

Sagala, S. 2013. Konsep dan Makna Pembelajaran : Untuk Membantu Memecahkan Problematika Belajar dan Mengajar. Bandung: Alfabeta.

Sarniah, S., Anwar, C., dan Putra, R. W. Y. 2019. Pengaruh Model Pembelajaran Auditory Intellectually Repetition (AIR) Terhadap Kemampuan Pemahaman Konsep Matematis. Journal of Medives: Journal of Mathematics Education IKIP Veteran Semarang, Vol. 3(1) : 87-96.

Subchan, Winarni, Mufid, M.S., Fahim, K., dan Syaifudin, W.H. 2018. Matematika : Buku Guru/Kementerian Pendidikan dan Kebudayaan. Jakarta: Kementerian Pendidikan dan Kebudayaan.

Sumardyono, Priatna, N., dan Anggraena, Y. 2016. Model Pembelajaran Matematika, Statistika dan Peluang. Jakarta: Direktorat Jenderal Guru dan Tenaga Kependidikan.

Surur, M. dan Oktavia, S. T. 2019. Pengaruh Model Pembelajaran Discovery Learning Terhadap Pemahaman Konsep Matematika. Jurnal Pendidikan Edutama, Vol. 6(1) : 11-18.

Wijaya, T. U. U., Destiniar, dan Mulbasari, A. S. 2018. Kemampuan Pemahaman Konsep Matematis Siswa dengan Menggunakan Model Pembelajaran Auditory Intellectually Repetition (AIR). Makalah Pada Prosiding Seminar Nasional 21 Universitas PGRI Palembang, 05 Mei 2018. Hal: 431-435. ISBN 978-60252451-0-7. 